\title{
Sustained Pulmonary Hypertension and Right Ventricular Hypertrophy after Chronic Hypoxia in Mice with Congenital Deficiency of Nitric Oxide Synthase 3
}

\author{
Wolfgang Steudel, ${ }^{\star}$ Marielle Scherrer-Crosbie, ${ }^{\ddagger}$ Kenneth D. Bloch, ${ }^{\S}$ Jörg Weimann, ${ }^{\star}$ Paul L. Huang, ${ }^{\S}$ Rosemary C. Jones, ${ }^{\star}$ \\ Michael H. Picard, ${ }^{\ddagger}$ and Warren M. Zapol ${ }^{\star}$ \\ *Department of Anesthesia and Critical Care, ${ }^{\ddagger}$ Cardiac Unit, and ${ }^{\S}$ Cardiovascular Research Center of the Department of Medicine, \\ Massachusetts General Hospital, Harvard Medical School, Boston, Massachusetts 02114
}

\begin{abstract}
Chronic hypoxia induces pulmonary hypertension and right ventricular (RV) hypertrophy. Nitric oxide (NO) has been proposed to modulate the pulmonary vascular response to hypoxia. We investigated the effects of congenital deficiency of endothelial NO synthase (NOS3) on the pulmonary vascular responses to breathing $11 \%$ oxygen for 3-6 wk. After 3 wk of hypoxia, RV systolic pressure was greater in NOS3-deficient than in wild-type mice $(35 \pm 2$ vs $28 \pm 1$ $\mathrm{mmHg}, \overline{\mathrm{x}} \pm \mathrm{SE}, P<\mathbf{0 . 0 0 1})$. Pulmonary artery pressure $\left(\mathrm{P}_{\mathrm{PA}}\right)$ and incremental total pulmonary vascular resistance $\left(R_{P I}\right)$ were greater in NOS3-deficient than in wild-type mice $\left(\mathrm{P}_{\mathrm{PA}}\right.$ $22 \pm 1$ vs $19 \pm 1 \mathrm{mmHg}, P<0.05$ and $\mathrm{R}_{\mathrm{PI}} 92 \pm 11$ vs $55 \pm 5$ $\left.\mathrm{mmHg} \cdot \mathrm{min} \cdot \mathrm{gram} \cdot \mathrm{ml}^{-1}, P<0.05\right)$. Morphometry revealed that the proportion of muscularized small pulmonary vessels was almost fourfold greater in NOS3-deficient mice than in wild-type mice. After 6 wk of hypoxia, the increase of $\mathrm{RV}$ free wall thickness, measured by transesophageal echocardiography, and of $\mathrm{RV}$ weight/body weight ratio were more marked in NOS3-deficient mice than in wildtype mice ( $R V$ wall thickness $0.67 \pm 0.05$ vs $0.48 \pm 0.02 \mathrm{~mm}$, $P<0.01$ and $\mathrm{RV}$ weight/body weight ratio $2.1 \pm 0.2 \mathrm{vs}$ $1.6 \pm 0.1 \mathrm{mg} \cdot$ gram $\left.^{-1}, P<0.05\right)$. RV hypertrophy produced by chronic hypoxia was prevented by breathing 20 parts per million NO in both genotypes of mice. These results suggest that congenital NOS3 deficiency enhances hypoxic pulmonary vascular remodeling and hypertension, and RV hypertrophy, and that NO production by NOS3 is vital to counterbalance pulmonary vasoconstriction caused by chronic hypoxic stress. (J. Clin. Invest. 1998. 101:2468-2477.) Key words: nitric oxide synthase - hypertension, pulmonary • circulation, pulmonary - echocardiography, transesophageal • gene deletion
\end{abstract}

\section{Introduction}

Nitric oxide synthase $3(\mathrm{NOS} 3)^{1}$ is expressed in normal human pulmonary vascular endothelial cells (1) and participates in the

Address correspondence to Warren M. Zapol, Reginald Jenney Professor of Anaesthesia, Department of Anesthesia and Critical Care, Massachusetts General Hospital, Harvard Medical School, 32 Fruit Street, Boston, MA 02114. Phone: 617-726-3030; FAX: 617-726-3032; E-mail: zapol@etherdome.mgh.harvard.edu

Received for publication 25 November 1997 and accepted in revised form 1 April 1998.

J. Clin. Invest.

(C) The American Society for Clinical Investigation, Inc. 0021-9738/98/06/2468/10 \$2.00

Volume 101, Number 11, June 1998, 2468-2477

http://www.jci.org control of the normal murine pulmonary vascular tone (2) by synthesizing NO which stimulates vascular smooth muscle cGMP synthesis and causes vasorelaxation (3). The role of endothelial NO synthesis in the pathogenesis of chronic pulmonary hypertension remains controversial. Studying pulmonary vascular specimens obtained from patients with chronic pulmonary hypertension, Giaid et al. reported decreased NOS3 expression and concluded that the reduction of this vasodilator enzyme contributed to the course of pulmonary hypertension (1). In contrast, Xue et al. (4) observed increased pulmonary vascular NOS3 expression in patients with pulmonary hypertension.

Experimental studies have examined the role of NOS3 in pulmonary hypertension, primarily by using chronic exposure to low ambient oxygen tensions to induce pulmonary hypertension, pulmonary vascular remodeling, and right ventricular (RV) hypertrophy, similar to that observed in pulmonary hypertensive patients $(5,6)$. Exposure of rats to chronic hypoxia decreases basal and stimulated cGMP synthesis by isolated main pulmonary arteries (7) and decreases endothelium-dependent vasodilation in isolated perfused lungs (8), suggesting decreased NO production (7). However, in this hypoxic rat model, an increase of total lung NOS3 mRNA and protein expression, as well as enzyme activity have been reported (9), and the increased pulmonary NOS3 expression was localized to the pulmonary vascular endothelium (10).

To investigate the contribution of NOS enzymes to chronic hypoxic pulmonary hypertension, Hampl et al. (11) studied rats which were exposed to chronic hypoxia with and without simultaneous treatment with $N \omega$-nitro-L-arginine methylester (L-NAME), an NOS inhibitor: no changes of the degree of pulmonary hypertension and vascular remodeling or RV hypertrophy were caused by the administration of L-NAME. However, it should be noted that L-NAME (and many other NOS inhibitors) inhibit all NOS isoforms and that the two other isoforms present in the lung (NOS1 and NOS2) are reported to be upregulated with chronic hypoxia (10). It is therefore not possible to isolate the role of NOS3 from other NOS isoforms by using nonselective NOS inhibitors.

The present study was designed to selectively study the role of NOS3 in chronic hypoxic pulmonary hypertension. We in-

1. Abbreviations used in this paper: $\mathrm{d}_{\mathrm{RVfw}}$, right ventricular free wall thickness (TEE); $\mathrm{FiO}_{2}$, inspiratory fraction of oxygen; L-NAME, $\mathrm{N}_{\omega^{-}}$ nitro-L-arginine methylester; NO, nitric oxide; NOS3, nitric oxide synthase $3 ; \mathrm{P}_{\mathrm{PA}}$, mean pulmonary artery pressure; $\mathrm{P}_{\mathrm{PC}}$, pulmonary vascular closing pressure; $\mathrm{P}_{\mathrm{SA}}$, mean systemic arterial pressure; $\mathrm{P}_{\mathrm{RVS}}$, right ventricular systolic pressure; $\mathrm{Q}_{\mathrm{LTA}}$, mean lower thoracic aortic flow; $\mathrm{R}_{\mathrm{PI}}$, incremental total pulmonary vascular resistance; $\mathrm{RV}$, right ventricular; TEE, transesophageal echocardiography; $\mathrm{V}_{\mathrm{RVED}}$, right ventricular end-diastolic volume (TEE); $\mathrm{W}_{\mathrm{B}}$ or bw, body weight; $\mathrm{W}_{\mathrm{RV}}$, right ventricular weight. 
vestigated mice with a congenital deficiency of NOS3, which exhibit major systemic (12) and mild pulmonary hypertension under normoxic conditions (2). Mice were exposed to an environment of low ambient oxygen tensions (11\%) for 3-6 wk. In additional studies, NO gas (20 parts per million, ppm) was added to this environment to test whether the consequences of NOS3 deficiency during hypoxia could be modified by exogenously substituted NO. RV pressure and echocardiographic $\mathrm{RV}$ dimensions and function were measured in closed-chest anesthetized mice to obtain values with minimal invasion. In addition, hemodynamic measurements including pulmonary artery pressure-flow relationships were obtained at thoracotomy. Neomuscularization of small intraacinar pulmonary vessels was analyzed by $\alpha$-smooth muscle actin staining and quantitative morphometry. We report that congenital NOS3 deficiency aggravated the degree of pulmonary vascular remodeling, RV hypertrophy, and pulmonary hypertension in mice chronically breathing at low oxygen tensions.

\section{Methods}

After institutional approval by the Massachusetts General Hospital Subcommitee on Research Animal Care, we studied NOS3-deficient mice, and wild-type mice of both of the parental strains of NOS3-deficient mice, SV129 and C57 Black/6. Mice of both sexes with an age range of $2-5$ mo, weighing 18-30 grams, were used for the experiments. The generation of these NOS3-deficient mice has been described by Huang et al. (12).

\section{Exposure to a low oxygen environment and $\mathrm{NO}$}

Mice breathed at an inspired oxygen fraction $\left(\mathrm{FiO}_{2}\right)$ of 0.11 , with or without $20 \mathrm{ppm} \mathrm{NO}$, for 21 and $42 \mathrm{~d}$, as previously described in detail (13). Mice breathed $20 \mathrm{ppm}$ NO because that level of inhaled NO caused a profound reduction of pulmonary vascular remodeling and RV hypertrophy in both newborn and adult rats $(13,14)$. After chronic exposure, mice were removed from the chambers and breathed air for a maximum of $2 \mathrm{~h}$ until the induction of anesthesia. During the hemodynamic or echocardiographic experiments, mice breathed at $\mathrm{FiO}_{2} 0.8$.

\section{Hemodynamic studies at closed chest and at thoracotomy}

Mice were anesthetized with an intraperitoneal injection of ketamine $(0.1 \mathrm{mg} / \mathrm{gram}$ body weight $[\mathrm{bw}])$. Tracheostomy and arterial catheterization were performed as previously described (2). Volume-controlled ventilation was initiated at a respiratory rate of $110-120 / \mathrm{min}$, an inspired oxygen fraction of 1.0, a peak inspiratory pressure of $13 \mathrm{~cm}$ $\mathrm{H}_{2} \mathrm{O}$ and a positive end-expiratory pressure level of $1 \mathrm{~cm} \mathrm{H}_{2} \mathrm{O}$. A $10-\mathrm{cm}$ silicone catheter (outer diameter $0.06 \mathrm{~mm}$ ) was introduced into the right jugular vein via a venotomy and passed across the tricuspid valve into the right ventricle to measure $\mathrm{RV}$ pressure with an intact chest. In additional experiments, a right parasternal thoracotomy was performed and pulmonary artery catheter and lower thoracic aortic flow probe were placed as previously reported (2). Anesthesia in all hemodynamic and echocardiographic experiments was maintained with high-dose intraperitoneal (i.p.) ketamine $(0.1 \mathrm{mg} / \mathrm{gram}$ bw) and xylazine $(0.01 \mathrm{mg} / \mathrm{gram} \mathrm{bw})$ injections with i.p. pancuronium $(0.002$ $\mathrm{mg}$ /gram bw; Gensia Pharmaceuticals, Irvine, CA) added to produce muscle relaxation.

\section{Blood pressure and flow measurements}

Mean systemic arterial pressure $\left(\mathrm{P}_{\mathrm{SA}}\right)$, mean pulmonary artery pressure $\left(\mathrm{P}_{\mathrm{PA}}\right)$, and $\mathrm{RV}$ systolic pressure $\left(\mathrm{P}_{\mathrm{RVS}}\right)$ were continuously monitored using biomedical amplifiers (Hewlett Packard 8805C; Andover, MA and Siemens Sirecust 960, Danvers, MA). Mean lower thoracic aortic flow $\left(\mathrm{Q}_{\mathrm{LTA}}\right)$ was measured with a small vessel flow-probe connected to a flowmeter (T106; Transonic Instruments, Ithaca, NY). All measured signals were transferred to an analog-to-digital converter and displayed on a computer screen and recorded at $1,500 \mathrm{~Hz}$ using a data acquisition system (DI 220; Dataq Instruments, Akron, OH). All monitoring equipment was calibrated before each experiment. As previously described in detail (2), the inferior vena cava was partially occluded with a circumferential 4-0 silk ligature to transiently reduce the $\mathrm{Q}_{\mathrm{LTA}}$ by a maximum of $60-80 \%$ for $2-3 \mathrm{~s}$ to obtain pressure-flow relationships. The slope $\left(\mathrm{R}_{\mathrm{PI}}=\right.$ incremental total pulmonary vascular resistance $)$ and intercept $\left(\mathrm{P}_{\mathrm{PC}}=\right.$ pulmonary vascular closing pressure $)$ of the $\mathrm{P}_{\mathrm{PA}} / \mathrm{Q}_{\mathrm{LTA}}$ relationship were calculated using a two-point analysis, reporting the values before occlusion and after transient $\mathrm{Q}_{\mathrm{LTA}}$ reduction.

\section{Interventions during hemodynamic experiments}

Acute NO inhalation. Nitric oxide was delivered from an $800 \mathrm{ppm}$ tank (BOC Gases Inc., Murray Hill, NJ) via a rotameter and mixed with oxygen. Inspired concentrations were sampled at a side-port before entering the respirator and measured by chemiluminescence. The inspired oxygen fraction was maintained constant at 0.8 before and throughout each NO inhalation study by adding nitrogen to the inspired gas mixture. A dry soda lime filter within the inspiratory limb removed $\mathrm{NO}_{2}$.

Hemodilution experiments. To assess hemodynamic effects at varying hematocrit levels, $1 \mathrm{ml}$ blood was slowly withdrawn from the arterial line and replaced by $1 \mathrm{ml}$ of $5 \%$ bovine albumin dissolved in lactated Ringer's solution injected intravenously over $5 \mathrm{~min}$, maintaining a constant $\mathrm{Q}_{\mathrm{LTA}}$ during the replacement procedure.

\section{Quantitative morphometry}

After pentobarbital euthanasia $(0.1 \mathrm{mg} / \mathrm{gram}$ i.p. $)$, the trachea was cannulated and $3 \%$ paraformaldehyde $/ 0.1 \%$ glutaraldehyde in phosphate buffered saline was infused into the trachea at $23 \mathrm{~cm} \mathrm{H}_{2} \mathrm{O}$ perfusion pressure. Lung tissue was kept in 3\% paraformaldehyde/ $01 \%$ glutaraldehyde for $24 \mathrm{~h}$, then dehydrated and embedded in paraffin wax. In $5-\mu \mathrm{m}$ sections of the left lung, the degree of alveolar distension, the distribution of macrophages, erythrocytes and leukocytes, and vessel diameter and structure were examined. We used a Histostain SP Kit (Zymed, South San Francisco, CA) and a monoclonal antibody against $\alpha$-smooth muscle actin (Sigma Chemical Co., St. Louis, MO) at a dilution of 1:400 with aminoethylcarbazole as the chromogen, and hematoxylin as the counterstain, to stain smooth muscle cells and to identify muscular vessels.

Vessels from the lungs of each animal were landmarked by their location, i.e., associated with bronchioli, terminal or respiratory bronchioli, alveolar ducts, or lying in the alveolar wall. When $\alpha$-smooth muscle actin-positive cells forming a single or multiple subendothelial layer encompassed $>75 \%$ of the circumference, a vessel was termed muscular, when $<75 \%$, partially muscular. When the vessel wall consisted only of endothelial cells and $\alpha$-smooth muscle actin staining was absent, the vessel was termed nonmuscular. Alveolar duct and wall vessels were analyzed quantitatively: 50 alveolar vessels per animal were recorded by wall structure and size.

\section{Transesophageal echocardiography}

In additional groups of mice, transesophageal echocardiography (TEE) was performed. Anesthesia and mechanical ventilation were performed as described above. The echocardiography system consisted of an intravascular echocardiograph (HP Sonos, Andover, MA) and a 3.5 French/30 MHz intravascular ultrasound probe (Sonicath; Boston Scientific Corporation, Watertown, MA). This system allows two-dimensional imaging with a maximal frame rate of $30 \mathrm{~Hz}$ and an axial resolution of $100 \mu \mathrm{m}$ at $7 \mathrm{~mm}$. After filling the esophagus with gel, the probe was inserted and advanced until the liver was visualized. The TEE probe was then manually withdrawn, in steps of $1 \mathrm{~mm}$ with a duration of $5 \mathrm{~s}$ for each plane. Four to six cross-sectional parallel planes of the heart were obtained. The RV endocardial borders were traced on 30 consecutive frames in each plane, yielding $30 \mathrm{RV}$ areas for each plane. The end-diastolic area was defined as the largest area, and the end-systolic area as the smallest area that we measured. 
End-diastolic and end-systolic $\mathrm{RV}$ volumes $\left(\mathrm{V}_{\mathrm{RVED}}, \mathrm{V}_{\mathrm{RVES}}\right)$ were then calculated by Simpson's method. Stroke volume was defined as $V_{R V E D}-V_{R V E S}$, and $R V$ ejection fraction as $\left(V_{R V E D}-V_{R V E S}\right) / V_{R V E D}$. $R V$ cardiac output was calculated as (RV stroke volume) (heart rate). The $\mathrm{RV}$ free wall thickness $\left(\mathrm{d}_{\mathrm{RVfw}}\right)$ was also assessed by obtaining 10 measurements per plane (five in diastole, five in systole) below the tricuspid valve. The mean value was considered to be representative of $d_{R V f w}$. This echocardiographic method in mice has been validated by the investigators $(15,16$, and Scherrer-Crosbie, M., W. Steudel, P.R. Hunziker, G.P. Foster, L. Garrido, N. Liel-Cohen, W.M. Zapol, M.H. Picard, manuscript submitted for publication). In the present study, analysis of the echocardiographic data was performed by two investigators who were blinded as to the mouse genotype and to the exposure conditions and duration.

\section{Ventricular weight}

At the end of each experiment, the heart was excised from the thoracic cavity, the atria removed, and the RV free wall was separated from the left ventricle including the septum. Tissues were blotted and weighed using a scale (XE 100E; Denver Instruments, Arvada, CO). Right and left ventricular weights were expressed as a function of the body weight $\left(\mathrm{W}_{\mathrm{RV}} / \mathrm{W}_{\mathrm{B}}\right.$ and $\mathrm{W}_{\mathrm{LV}} / \mathrm{W}_{\mathrm{B}}$, respectively) and the ratio of the $\mathrm{RV}$ to the left ventricular weight $\left(\mathrm{W}_{\mathrm{RV}} / \mathrm{W}_{\mathrm{LV}}\right.$, Fulton's ratio) was calculated.

\section{Experimental groups}

A total of 222 mice were investigated in this study. SV129 wild-type mice $(n=27)$, C57 Black/6 wild-type mice $(n=10)$, and NOS3-deficient mice $(n=27)$ were studied under normoxic control conditions. SV129 wild-type mice $(n=50)$, C57 Black/6 wild-type mice $(n=10)$, and NOS3-deficient mice $(n=48)$ breathed at $\mathrm{FiO}_{2} 0.11$ for 3 wk, and SV129 wild-type mice $(n=5)$ and NOS3-deficient mice $(n=5)$ breathed at $\mathrm{FiO}_{2} 0.11$ for $6 \mathrm{wk}$. Additionally, SV129 wild-type mice $(n=20)$ and NOS3-deficient mice $(n=20)$ breathed at $\mathrm{FiO}_{2} 0.11$ with $20 \mathrm{ppm} \mathrm{NO}$ added for $3 \mathrm{wk}$. None of the mice died during exposure. Approximately $3 \%$ of chronically hypoxic mice in all groups died during the induction of anesthesia.

The results of hemodynamic and echocardiographic experiments were omitted from analysis if a cardiac arrhythmia or hemorrhage occurred, or if substantial changes of $\mathrm{P}_{\mathrm{SA}}(>10 \mathrm{mmHg})$, peak inspiratory pressure or positive end-expiratory pressure were measured during the placement of the TEE probe. Groups were matched for animal age, body weight and gender before exposure.

\section{Statistical analysis}

Differences between groups were determined using an unpaired Student's $t$ test. The effects of interventions were analyzed using a paired $t$ test. A statistically significant difference was assumed with a $P$ value below 0.05 . All data are expressed as mean $(\overline{\mathrm{x}}) \pm$ standard error.

\section{Results}

$R V$ pressure measurements with an intact chest. In normoxic NOS3-deficient mice, the initial $\mathrm{P}_{\mathrm{RVS}}$ was greater than in normoxic SV129 wild-type mice $(24 \pm 1$ vs $19 \pm 1 \mathrm{mmHg}, P<0.01$, Fig. 1). Under normoxic conditions the $P_{R V S}$ in C57 Black/6 wild-type mice $(n=5)$ did not differ from the $\mathrm{P}_{\mathrm{RVS}}$ in SV129 wild-type mice ( $n=8, P=\mathrm{NS}$, data not shown). In both SV129 wild-type and NOS3-deficient mice, $\mathrm{P}_{\mathrm{RVs}}$ increased $(P<0.001)$ with 3 wk of breathing at $\mathrm{FiO}_{2} 0.11$ (Fig. 1). The $\mathrm{P}_{\mathrm{RVS}}$ of these chronically hypoxic NOS3-deficient mice was substantially greater than the $\mathrm{P}_{\mathrm{RVs}}$ of chronically hypoxic SV129 wild-type mice $(35 \pm 2$ vs $28 \pm 1 \mathrm{mmHg}, P<0.001$, Fig. 1). The $P_{\text {RVs }}$ of C57 Black/6 mice that breathed for 3 wk at $\mathrm{FiO}_{2} 0.11$ did not differ from the values obtained from similarly exposed SV129 mice $(25 \pm 1 \mathrm{mmHg}, P=\mathrm{NS})$.

In both SV129 wild-type and NOS3-deficient mice that

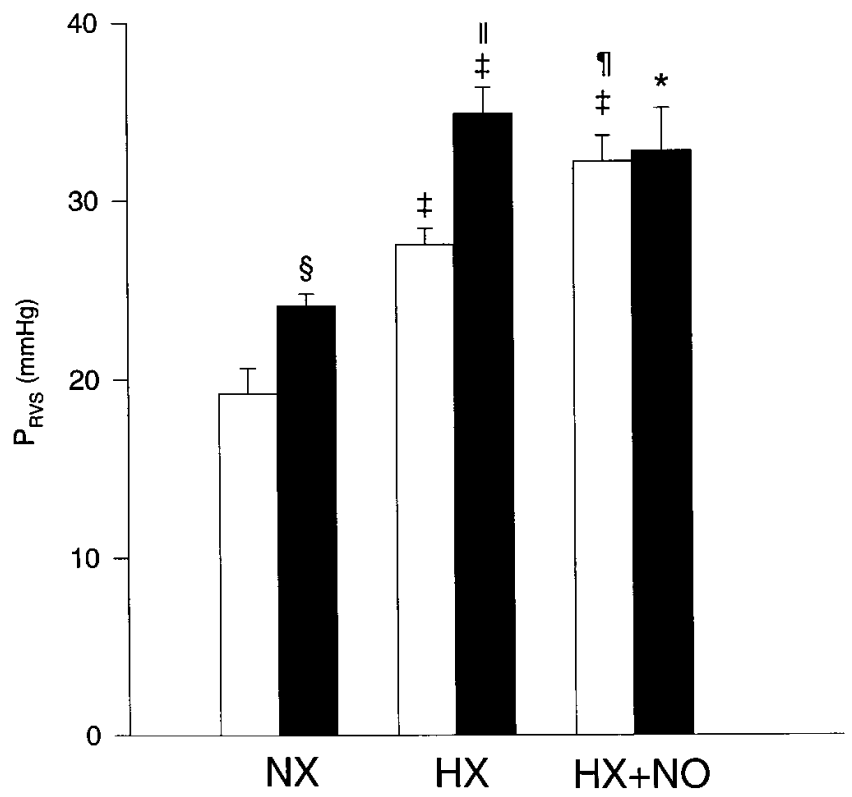

Figure 1. RV systolic pressure $\left(P_{R V S}\right)$ measurements in SV129 wildtype (open bars) and NOS3-deficient mice (solid bars) under normoxic conditions $(N X)$, after 3 wk of breathing at $\mathrm{FiO}_{2} 0.11(H X)$ and after 3 wk of breathing at $\mathrm{FiO}_{2} 0.11$ with 20 ppm NO added $(H X+$ $N O)$. Note systolic RV hypertension in NOS3-deficient mice which was enhanced by chronic hypoxia, independent of chronic NO inhalation. $* P<0.01,{ }^{\ddagger} P<0.001$ value differs significantly from value of corresponding normoxic group. ${ }^{\S} P<0.01,{ }^{\|} P<0.001$ value differs significantly from value of wild-type mice in the same exposure group. ${ }^{\text {I }} P<0.05$ value differs significantly from value of corresponding HX group. Data are $\overline{\mathrm{X}} \pm \mathrm{SE}$ of independent experiments: $\mathrm{NOS} 3+/+\mathrm{NX}(n=8), \mathrm{NOS} 3-/-\mathrm{NX}(n=9), \mathrm{NOS} 3+/+\mathrm{HX}$ $(n=16), \mathrm{NOS} 3-/-\mathrm{HX}(n=18), \mathrm{NOS} 3+/+\mathrm{HX}+\mathrm{NO}(n=11)$, NOS3-/- HX + NO $(n=8)$.

breathed at $\mathrm{FiO}_{2} 0.11$ with 20 ppm $\mathrm{NO}$ for 3 wk, the $\mathrm{P}_{\mathrm{Rvs}}$ was greater than in the corresponding normoxic group $(P<0.001$ and $P<0.01$ respectively, Fig. 1$)$. The $\mathrm{P}_{\mathrm{RVs}}$ in SV129 wild-type mice that breathed at $\mathrm{FiO}_{2} 0.11$ with 20 ppm NO for 3 wk was greater than that in SV129 wild-type mice that breathed at $\mathrm{FiO}_{2} 0.11$ without $\mathrm{NO}(P<0.05)$. The $\mathrm{P}_{\mathrm{RVS}}$ of NOS3-deficient mice that breathed at $\mathrm{FiO}_{2} 0.11$ with 20 ppm NO for 3 wk was not different from that of NOS3-deficient mice that breathed at $\mathrm{FiO}_{2} 0.11$ without $\mathrm{NO}(P=\mathrm{NS})$. There was no difference in $\mathrm{P}_{\mathrm{RVS}}$ between NOS3-deficient and SV129 wild-type mice that breathed at $\mathrm{FiO}_{2} 0.11$ with 20 ppm NO added for 3 wk $(P=\mathrm{NS})$.

Hemodynamic measurements at thoracotomy. Before thoracotomy, the $\mathrm{P}_{\mathrm{SA}}$ was greater in NOS3-deficient mice that breathed for 3 wk at $\mathrm{FiO}_{2} 0.11$ than in SV129 wild-type mice that breathed for $3 \mathrm{wk}$ at $\mathrm{FiO}_{2} 0.11(P<0.001$, see Table I). After thoracotomy, the $\mathrm{P}_{\mathrm{PA}}$ and the $\mathrm{R}_{\mathrm{PI}}$ were greater in chronically hypoxic NOS3-deficient mice than in chronically hypoxic wild-type mice $\left(\mathrm{P}_{\mathrm{PA}} 22 \pm 1\right.$ vs $19 \pm 1 \mathrm{mmHg}, P<0.05 ; \mathrm{R}_{\mathrm{PI}}$ $92 \pm 11$ vs $55 \pm 5 \mathrm{mmHg} \cdot \mathrm{min} \cdot \mathrm{grams} \cdot \mathrm{ml}^{-1}, P<0.01$, see Table I). After breathing for $3 \mathrm{wk}$ at $\mathrm{FiO}_{2} 0.11$ with $\mathrm{NO}$ added, $\mathrm{P}_{\mathrm{PA}}$ and the $\mathrm{R}_{\mathrm{PI}}$ did not differ between SV129 wild-type mice and NOS3-deficient mice (see Table I). Hemodynamic measurements are summarized in Table I. Hemodynamic parameters obtained in C57 Black/6 wild-type mice $(n=5$, data not 
Table I. Hemodynamic Measurements at Thoracotomy

\begin{tabular}{lcccc}
\hline & $\mathrm{HX}$ & $\mathrm{HX}$ & $\mathrm{HX}+\mathrm{NO}$ & $\mathrm{HX}+\mathrm{NO}$ \\
& $\mathrm{NOS} 3+/+$ & $\mathrm{NOS} 3-/-$ & $\mathrm{NOS} 3+/+$ & $\mathrm{NOS} 3-/-$ \\
\hline$n$ & 19 & 14 & 12 & 12 \\
bw (grams) & $21.2 \pm 0.6$ & $20.6 \pm 0.8$ & $24.3 \pm 0.8$ & $22.2 \pm 0.5$ \\
$\mathrm{I}^{-} \mathrm{P}_{\mathrm{SA}}(\mathrm{mmHg})$ & $91 \pm 6$ & $127 \pm 7^{\S}$ & $92 \pm 9$ & $118 \pm 10$ \\
$\mathrm{HR}\left(\mathrm{min}^{-1}\right)$ & $466 \pm 20$ & $511 \pm 15$ & $502 \pm 28$ & $492 \pm 18$ \\
$\mathrm{Q}_{\mathrm{LTA}}\left(\mathrm{ml} \cdot \mathrm{min} \cdot \mathrm{gram}^{-1}\right)$ & $0.21 \pm 0.02$ & $0.16 \pm 0.02$ & $0.20 \pm 0.02$ & $0.18 \pm 0.03$ \\
$\mathrm{P}_{\mathrm{SA}}(\mathrm{mmHg})$ & $82 \pm 6$ & $94 \pm 7$ & $85 \pm 6$ & $74 \pm 9$ \\
$\mathrm{P}_{\mathrm{PA}}(\mathrm{mmHg})$ & $19 \pm 1$ & $22 \pm 1^{*}$ & $22 \pm 1$ & $24 \pm 1$ \\
$\mathrm{R}_{\mathrm{PI}}(\mathrm{mmHg} \cdot$ & & & & \\
$\left.\quad \mathrm{min} \cdot \mathrm{gram} \cdot \mathrm{ml}^{-1}\right)$ & $55 \pm 5$ & $92 \pm 11^{\ddagger}$ & $72 \pm 10$ & $79 \pm 9$ \\
$\mathrm{P}_{\mathrm{PC}}(\mathrm{mmHg})$ & $9 \pm 1$ & $10 \pm 1$ & $10 \pm 1$ & $12 \pm 1$ \\
& & & & \\
\hline
\end{tabular}

Central hemodynamic measurements in wild-type mice $(\mathrm{NOS} 3+/+)$ and NOS3-deficient mice (NOS3-/-) that breathed for 3 wk at $\mathrm{FiO}_{2}$ $0.11(H X)$ and that breathed for 3 wk at $\mathrm{FiO}_{2} 0.11$ with $20 \mathrm{ppm} \mathrm{NO}$ added $(H X+N O)$. bw, body weight; $\mathrm{I}_{-} \mathrm{P}_{\mathrm{SA}}$, initial systemic arterial pressure before thoracotomy; HR, heart rate before thoracotomy; $\mathrm{Q}_{\mathrm{LTA}}$, mean lower thoracic aortic flow; $\mathrm{P}_{\mathrm{SA}}$, systemic arterial pressure after thoracotomy; $\mathrm{P}_{\mathrm{PA}}$, pulmonary artery pressure; $\mathrm{R}_{\mathrm{PI}}$, incremental total pulmonary vascular resistance; $\mathrm{P}_{\mathrm{PC}}$, pulmonary vascular closing pressure. ${ }^{*} P<0.05 ;{ }^{\sharp} P<0.01 ;{ }^{\S} P<0.001$ value differs significantly from corresponding value of wild-type mice. Data $\bar{x} \pm S E$.

shown) after 3 wk of breathing at $\mathrm{FiO}_{2} 0.11$ did not differ from those of similarly exposed SV129 wild-type mice $(n=19)$.

Pulmonary vasodilation in response to acute NO inhalation. To assess pulmonary vasoreactivity in response to acute NO inhalation, normoxic mice and mice that had breathed for 3 wk at $\mathrm{FiO}_{2} 0.11$ with and without 20 ppm NO added were studied. No significant effects on $\mathrm{P}_{\mathrm{RVS}}, \mathrm{P}_{\mathrm{PA}}$, and $\mathrm{R}_{\mathrm{PI}}$ were noted with the inhalation of $20 \mathrm{ppm}$ NO for $5 \mathrm{~min}$ in either SV129 wild-type or NOS3-deficient mice under normoxic conditions (data not shown).

After breathing at $\mathrm{FiO}_{2} 0.11$ for $3 \mathrm{wk}$, acute inhalation of 20 ppm NO caused no significant changes in $\mathrm{P}_{\mathrm{RVS}}, \mathrm{P}_{\mathrm{PA}}$, or $\mathrm{R}_{\mathrm{PI}}$ in both SV129 wild-type and NOS3-deficient mice $(P=$ NS, Fig. 2). In contrast, acute inhalation of $20 \mathrm{ppm}$ NO produced pulmonary vasodilation in mice that had chronically breathed at $\mathrm{FiO}_{2} 0.11$ with 20 ppm NO added (see Fig. 2). After chronic $\mathrm{NO}$ exposure, the $\mathrm{P}_{\mathrm{RVs}}$ was decreased with acute $\mathrm{NO}$ inhalation by $2.5 \pm 0.7 \mathrm{mmHg}$ in wild-type mice $(P<0.001)$ and by $2.9 \pm 0.6 \mathrm{mmHg}$ in NOS3-deficient mice $(P<0.01)$. The $\mathrm{P}_{\mathrm{PA}}$ decreased with acute $\mathrm{NO}$ inhalation by $-2 \pm 1 \mathrm{mmHg}(P<$ $0.01)$, and the $\mathrm{R}_{\mathrm{PI}}$ by $-12 \pm 7 \mathrm{mmHg} \cdot \mathrm{min} \cdot \mathrm{grams} \cdot \mathrm{ml}^{-1}(P<$ $0.05)$ and $-19 \pm 5 \mathrm{mmHg} \cdot \mathrm{min} \cdot \mathrm{grams} \cdot \mathrm{ml}^{-1}(P<0.01)$ in SV129 wild-type and NOS3-deficient mice, respectively (Fig. 2), but there was no difference noted between SV129 wild-type and NOS3-deficient mice. No significant changes of $\mathrm{P}_{\mathrm{SA}}$ were caused by the acute inhalation of $20 \mathrm{ppm}$ NO (data not shown).

Pulmonary vascular morphology. Bronchioli and vessels associated with bronchioli, terminal, and respiratory bronchioli were $\alpha$ smooth muscle actin-positive in both the normoxic and hypoxic lung. In the lungs of normoxic SV129 wild-type and NOS3-deficient mice, $\alpha$-smooth muscle actin-positive, partially muscular alveolar duct or wall vessels were rare; no completely muscular intraacinar vessels $(<100 \mu \mathrm{m}$ external diam-
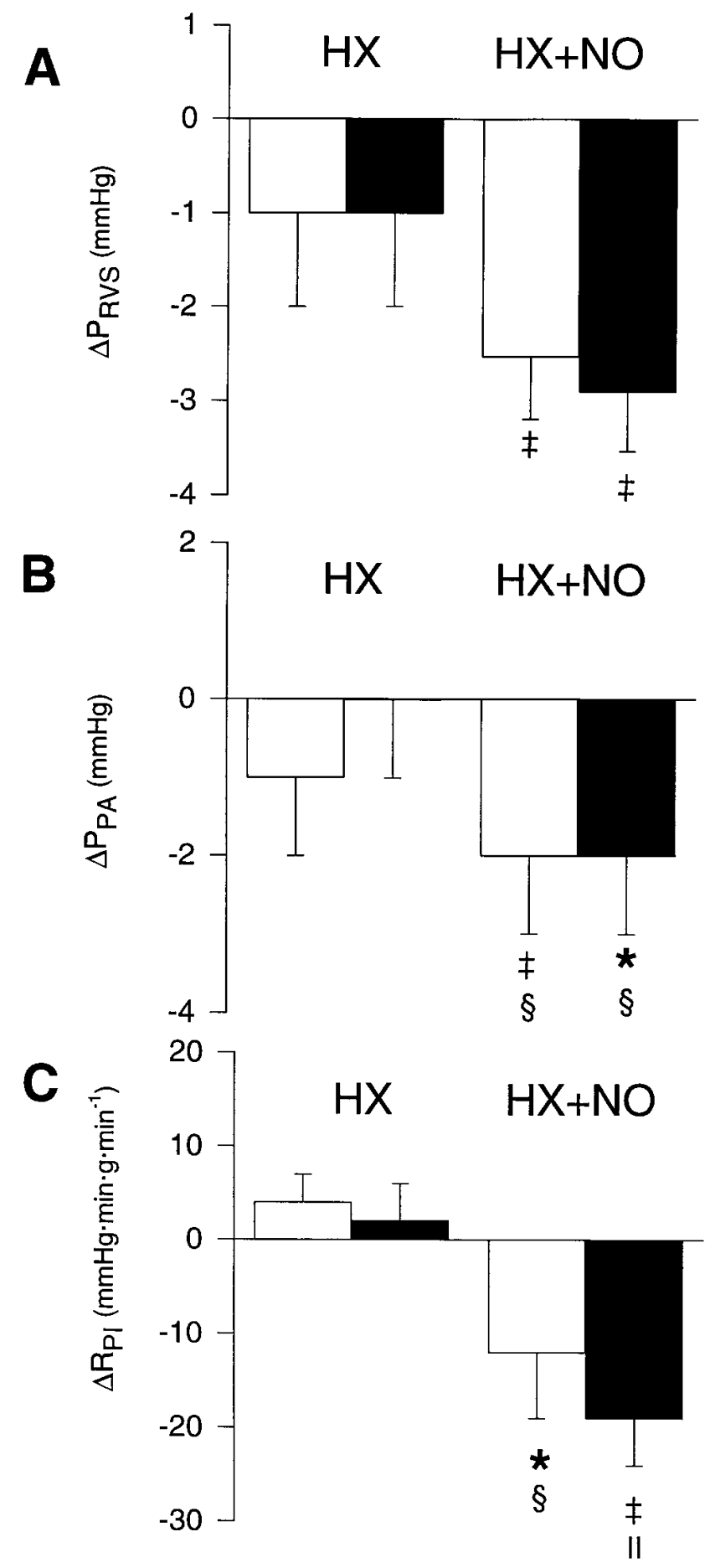

Figure 2. Pulmonary vasoreactivity to inhaled NO. The effect of acute NO inhalation (20 ppm for $5 \mathrm{~min}$ ) on RV systolic pressure was measured with an intact chest $\left(P_{R V S}, A\right)$. The effect of NO on pulmonary artery pressure $\left(P_{P A}, B\right)$ and incremental total pulmonary vascular resistance $\left(R_{P I}, C\right)$ was measured at thoracotomy. Both SV129 wild-type mice (open bars) and NOS3-deficient mice (solid bars) that chronically breathed at $\mathrm{FiO}_{2} 0.11$ with $20 \mathrm{ppm} \mathrm{NO}$ added $(H X+N O)$ exhibited vasodilation in response to acute $\mathrm{NO}$ inhalation, whereas mice that breathed at $\mathrm{FiO}_{2} 0.11$ without $\mathrm{NO}(H X)$ were unreactive. ${ }^{*} P<0.05,{ }^{\ddagger} P<0.01$ effect of NO inhalation different from zero. ${ }^{\S} P<$ $0.05,{ }^{\|} P<0.01$ effect of NO inhalation different as compared to HX group. Data are $\overline{\mathrm{x}} \pm \mathrm{SE}$ of independent experiments: NOS3 $+/+\mathrm{HX}$ $(n=8), \mathrm{NOS} 3-/-\mathrm{HX}(n=8), \mathrm{NOS} 3+/+\mathrm{HX}+\mathrm{NO}(n=11)$, NOS3-/- HX + NO $(n=8)$. 

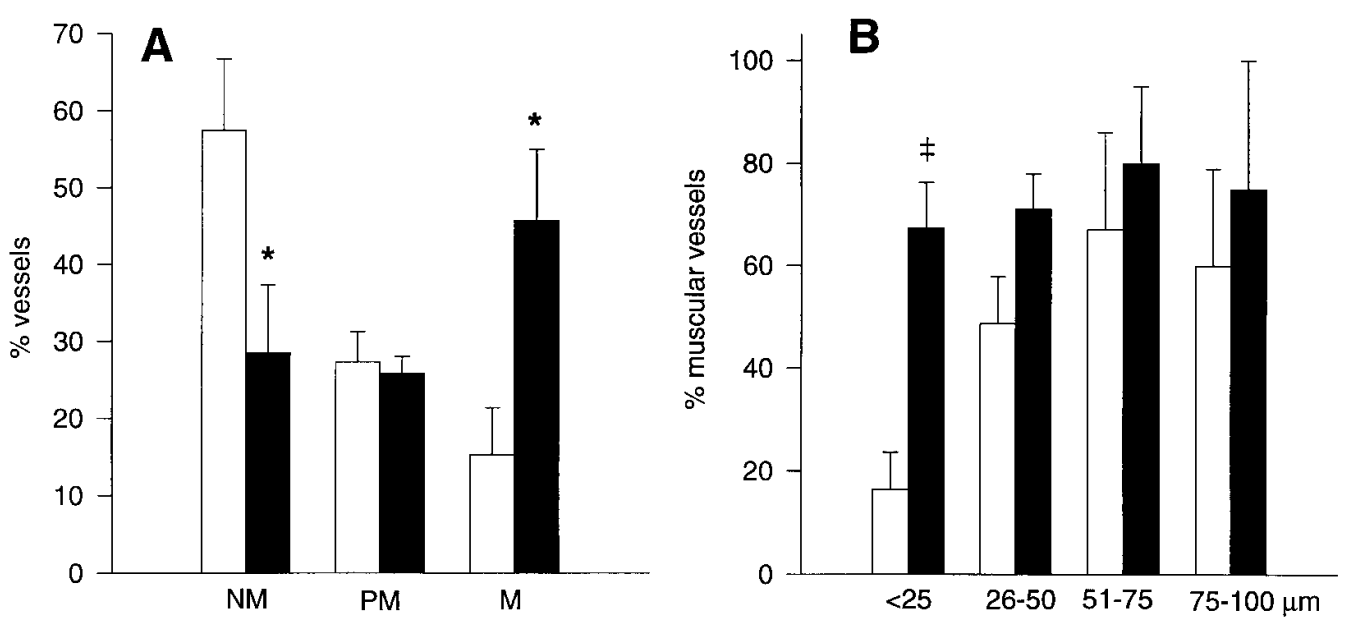

Figure 3. Quantitative morphometric analysis of neomuscularized pulmonary vessels during chronic hypoxia. (A) Proportion of nonmuscular $(N M)$, partially muscular $(P M)$, and completely muscular $(M)$ intraacinar vessels $(<100 \mu \mathrm{m}$ external diameter) in SV129 wild-type mice (open bars) and NOS3-deficient mice (solid bars) after 3 wk of breathing at $\mathrm{FiO}_{2} 0.11$. (B) Proportion of muscular vessels (complete and partially muscular), among vessels $<25,26-50,51-75,76-$ $100 \mu \mathrm{m}$ external diameter. Note that substanially more

$(P<0.01)$ vessels below $25 \mu \mathrm{m}$ external diameter were muscular in NOS3-deficient mice (solid bars), compared to SV129 wild-type mice (open bars) after 3 wk of breathing at $\mathrm{FiO}_{2} 0.11 .{ }^{*} P<0.05,{ }^{\ddagger} P<0.01$ value differs significantly from value of wild-type mice. Data are $\overline{\mathrm{x}} \pm$ SE of independent experiments: NOS3 $+/+\mathrm{HX}(n=5)$, NOS3 $-/-\mathrm{HX}(n=3)$.

eter) were detected under normoxic conditions (data not shown).

In both SV129 wild-type and NOS3-deficient mice that breathed for 3 wk at $\mathrm{FiO}_{2} 0.11$, nonmuscular, partially muscular, and completely muscular intraacinar vessels were present, but their proportion differed: In NOS3-deficient mice that breathed for $3 \mathrm{wk}$ at $\mathrm{FiO}_{2} 0.11,46 \pm 9 \%$ of vessels $(<100 \mu \mathrm{m}$ external diameter) were competely muscular, whereas only $15 \pm 6 \%$ of these vessels were completely muscular in SV129 wild-type mice that breathed at $\mathrm{FiO}_{2} 0.11$ for 3 wk $(P<0.05$, Fig. $3 A$ ). In NOS3-deficient mice that breathed for $3 \mathrm{wk}$ at $\mathrm{FiO}_{2} 0.11,67 \pm 9 \%$ of all vessels $<25 \mu \mathrm{m}$ in external diameter were muscular or partially muscular, whereas only $17 \pm 7 \%$ of these vessels were muscular or partially muscular in SV129 wild-type mice that breathed for 3 wk at $\mathrm{FiO}_{2} 0.11(P<0.01$, Fig. $3 B$ ).

Echocardiographic $R V$ dimensions and function. To obtain minimally invasive measurements of RV dimensions and function, transesophageal echocardiography was performed. Fig. 4 illustrates representative single frames of transesophageal echocardiograms obtained from SV129 wild-type mice and NOS3-deficient mice, after normoxic breathing (controls) and after breathing at $\mathrm{FiO}_{2} 0.11$ for 6 wk.

The RV free wall thickness $\left(\mathrm{d}_{\mathrm{RVfw}}\right.$, Fig. $\left.5 A\right)$, measured at the mid-ventricular level, was $0.38 \pm 0.01 \mathrm{~mm}$ in SV129 wildtype mice and $0.44 \pm 0.03 \mathrm{~mm}$ in NOS3-deficient mice under normoxic conditions $(P=\mathrm{NS})$. After breathing at $\mathrm{FiO}_{2} 0.11$ for $6 \mathrm{wk}$ without $\mathrm{NO}$ added, the $\mathrm{d}_{\mathrm{RVfw}}$ increased in both genotypes $(P<0.01)$. The $\mathrm{d}_{\mathrm{RVfw}}$ increased to a greater extent in NOS3-deficient mice as compared to wild-type mice $(0.67 \pm 0.05$ vs $0.48 \pm 0.02 \mathrm{~mm}, P<0.05$ values differ $)$. Both $\mathrm{RV}$ end-diastolic volume $\left(\mathrm{V}_{\mathrm{RVED}}\right.$, Fig. $\left.5 \mathrm{~B}\right)$ and $\mathrm{RV}$ end-systolic volume increased with the duration of hypoxia, but SV129 wild-type and NOS3-deficient mice did not differ. Under normoxic conditions, the calculated RV stroke volume was $0.52 \pm 0.09$ and $0.58 \pm 0.1 \mu \mathrm{l} \cdot \mathrm{gram}^{-1}$ bw in SV129 wild-type mice and NOS3-deficient mice, respectively. The RV stroke volume did not change in either genotype after 3 wk at $\mathrm{FiO}_{2} 0.11$ or in NOS3-deficient mice after 6 wk at $\mathrm{FiO}_{2}$ 0.11. However, in
SV129 wild-type mice that breathed at $\mathrm{FiO}_{2} 0.11$ for 6 wk, the $\mathrm{RV}$ stroke volume was increased in comparison to normoxic SV129 wild-type mice $\left(0.87 \pm 0.04\right.$ vs $0.52 \pm 0.09 \mu \mathrm{l} \cdot \mathrm{gram}^{-1} \mathrm{bw}$, $P<0.05)$. The RV ejection fraction was moderately reduced in mice that breathed at $\mathrm{FiO}_{2} 0.11$ for 6 wk as compared with values of normoxic mice (SV129 mice, $47 \pm 1$ vs $52 \pm 5 \%, P<$ 0.05 and NOS 3 -deficient mice, $45 \pm 2$ vs $54 \pm 2 \%, P<0.05$ ). The RV cardiac output was $0.30 \pm 0.03$ and $0.31 \pm 0.05 \mathrm{ml} \cdot \mathrm{min}^{-1}$. gram $^{-1}$ in SV129 wild-type mice and NOS3-deficient mice under normoxic conditions, respectively. No changes in RV cardiac output were measured in both genotypes that breathed at $\mathrm{FiO}_{2} 0.11$ for $3 \mathrm{wk}$ or in NOS3-deficient mice that breathed at $\mathrm{FiO}_{2} 0.11$ for $6 \mathrm{wk}$; however, in SV129 wild-type mice that breathed at $\mathrm{FiO}_{2} 0.11$ for $6 \mathrm{wk}$, the RV cardiac output was significantly increased as compared to normoxic wild-type mice $\left(0.42 \pm 0.03\right.$ vs $\left.0.30 \pm 0.03 \mathrm{ml} \cdot \mathrm{min}^{-1} \cdot \mathrm{gram}^{-1}, P<0.05\right)$.

Body and ventricular weights. SV129 wild-type mice and NOS3-deficient mice were matched for body weight before hypoxic exposure. The loss of body weight over the $3 \mathrm{wk}$ of breathing at $\mathrm{FiO}_{2} 0.11$ did not differ between SV129 wild-type mice $(-3.4 \pm 1.7 \%$ of initial bw) and NOS3-deficient mice $(-3.6 \pm 1.7 \%$ of initial bw, $P=\mathrm{NS})$. The loss of body weight over 6 wk of breathing at $\mathrm{FiO}_{2} 0.11$ was larger in NOS3-deficient mice $(-6.0 \pm 1.9 \%$ of initial bw, $P<0.05)$ as compared with similarly treated SV129 wild-type mice $(-1.7 \pm 1.4 \%$ of initial bw). After breathing for 3 wk at $\mathrm{FiO}_{2} 0.11$ with 20 ppm NO added, the body weight changes did not differ between SV129 wild-type mice $(-1.9 \pm 2.9 \%$ of initial bw) and NOS3deficient mice $(+0.1 \pm 2.0 \%$ of initial bw, $P=\mathrm{NS})$.

The initial ratio of RV weight to body weight was greater in NOS3-deficient mice than in SV129 wild-type mice $(1.1 \pm 0.1$ vs $\left.0.9 \pm 0.1 \mathrm{mg} \cdot \mathrm{gram}^{-1}, P<0.001\right)$ under normoxic conditions $\left(\mathrm{W}_{\mathrm{RV}} / \mathrm{W}_{\mathrm{B}}\right.$, Fig. $\left.6 A\right)$. Fulton's ratio $\left(\mathrm{W}_{\mathrm{RV}} / \mathrm{W}_{\mathrm{LV}}\right)$ was not different between SV129 wild-type and NOS3-deficient mice (Fig. 6 $B)$ under normoxic conditions. The ratio of left ventricular weight to bodyweight $\left(\mathrm{W}_{\mathrm{LV}} / \mathrm{W}_{\mathrm{B}}\right)$ in NOS3-deficient mice under normoxic conditions was greater than in normoxic SV129 wild-type mice and did not change after 3 or 6 wk of breathing at $\mathrm{FiO}_{2} 0.11$ with or without $\mathrm{NO}$ added (data not shown). In 

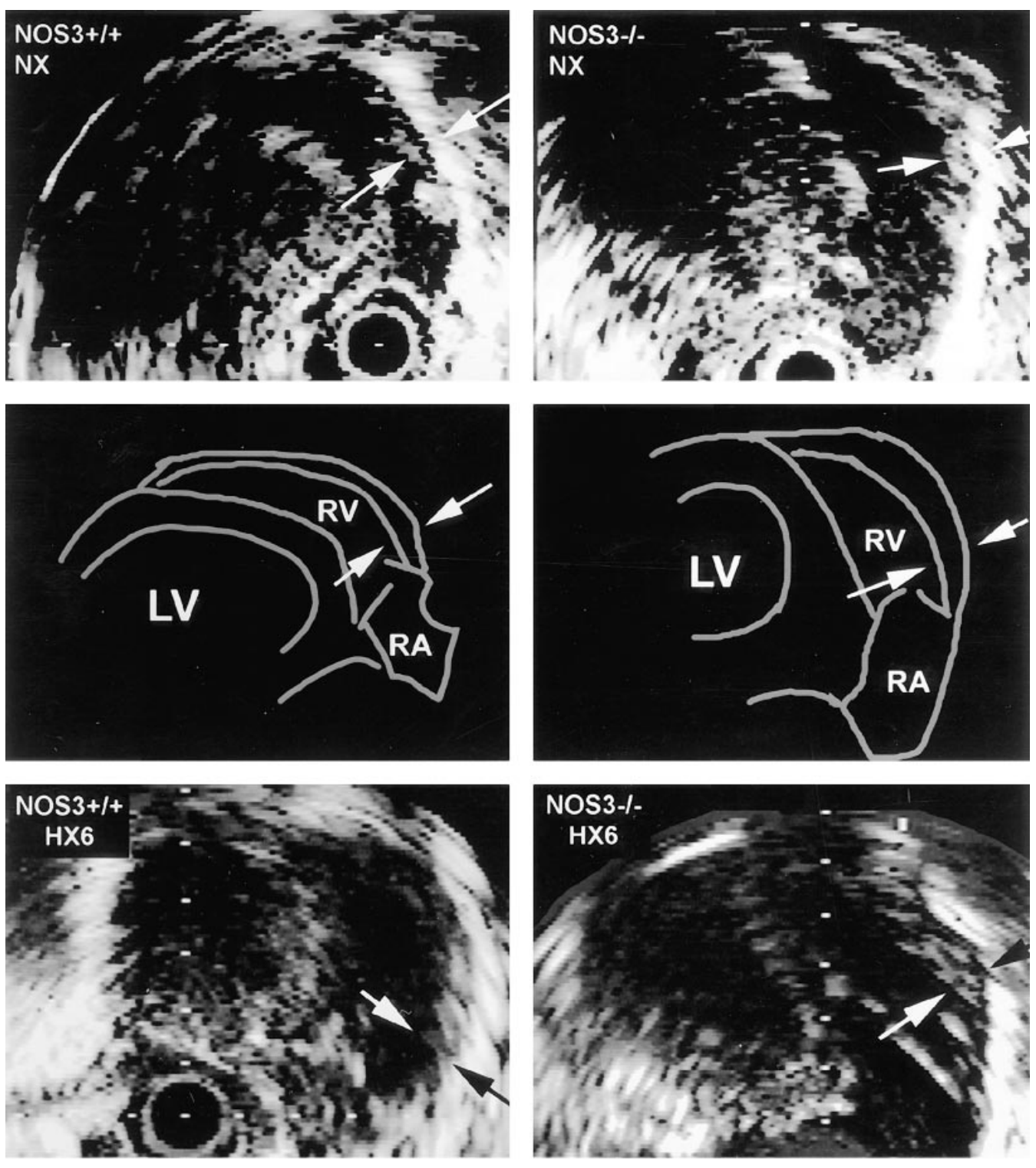

Figure 4. Transesophageal echocardiograms obtained at mid-ventricular level (enddiastole) from a normoxic SV129 wild-type mouse $(N O S 3+/+N X)$, from a normoxic NOS3-deficient mouse (NOS3-1-NX), from a SV129 wild-type mouse (NOS $3+/+H X 6)$, and from a NOS3-deficient mouse (NOS3-/-HX6) after $6 \mathrm{wk}$ breathing at $\mathrm{FiO}_{2} 0.11$. Endocardial and epicardial borders as well as the tricuspid leaflets are sketched below each echocardiogram to illustrate the ventricular contours as seen during in vivo echocardiography. Arrows indicate the site of RV wall thickness measurements. Note the increased RV wall thickness in the NOS3-deficient mouse after 6-wk breathing at $\mathrm{FiO}_{2}$ 0.11. The intervals between scaling points within the echocardiogram equal $1 \mathrm{~mm}$.

both SV129 wild-type mice and NOS3-deficient mice, 3 and 6 wk of chronic hypoxia led to increases in both $\mathrm{W}_{\mathrm{RV}} / \mathrm{W}_{\mathrm{B}}$ and $\mathrm{W}_{\mathrm{RV}} /$ $\mathrm{W}_{\mathrm{LV}}$ ratio $(P<0.001$, Fig. $6, A$ and $B)$. The $\mathrm{W}_{\mathrm{RV}} / \mathrm{W}_{\mathrm{B}}$ ratio was greater in hypoxic NOS3-deficient mice than in hypoxic wildtype mice $(P<0.001$ groups differ at $3 \mathrm{wk}$ and $P<0.05$ at 6 wk). In both SV129 wild-type mice and NOS3-deficient mice that breathed for 3 wk at $\mathrm{FiO}_{2} 0.11$ with 20 ppm NO added, the $\mathrm{W}_{\mathrm{RV}} / \mathrm{W}_{\mathrm{B}}$ ratio was substantially less than that of corresponding mice that breathed for $3 \mathrm{wk}$ at $\mathrm{FiO}_{2} 0.11$ without NO added $(P<0.001$, Fig. $6 A)$. The $\mathrm{W}_{\mathrm{RV}} / \mathrm{W}_{\mathrm{B}}$ ratio in both genotypes that breathed for $3 \mathrm{wk}$ at $\mathrm{FiO}_{2} 0.11$ with $\mathrm{NO}$ added did not differ from corresponding normoxic groups. Ventricular weights 

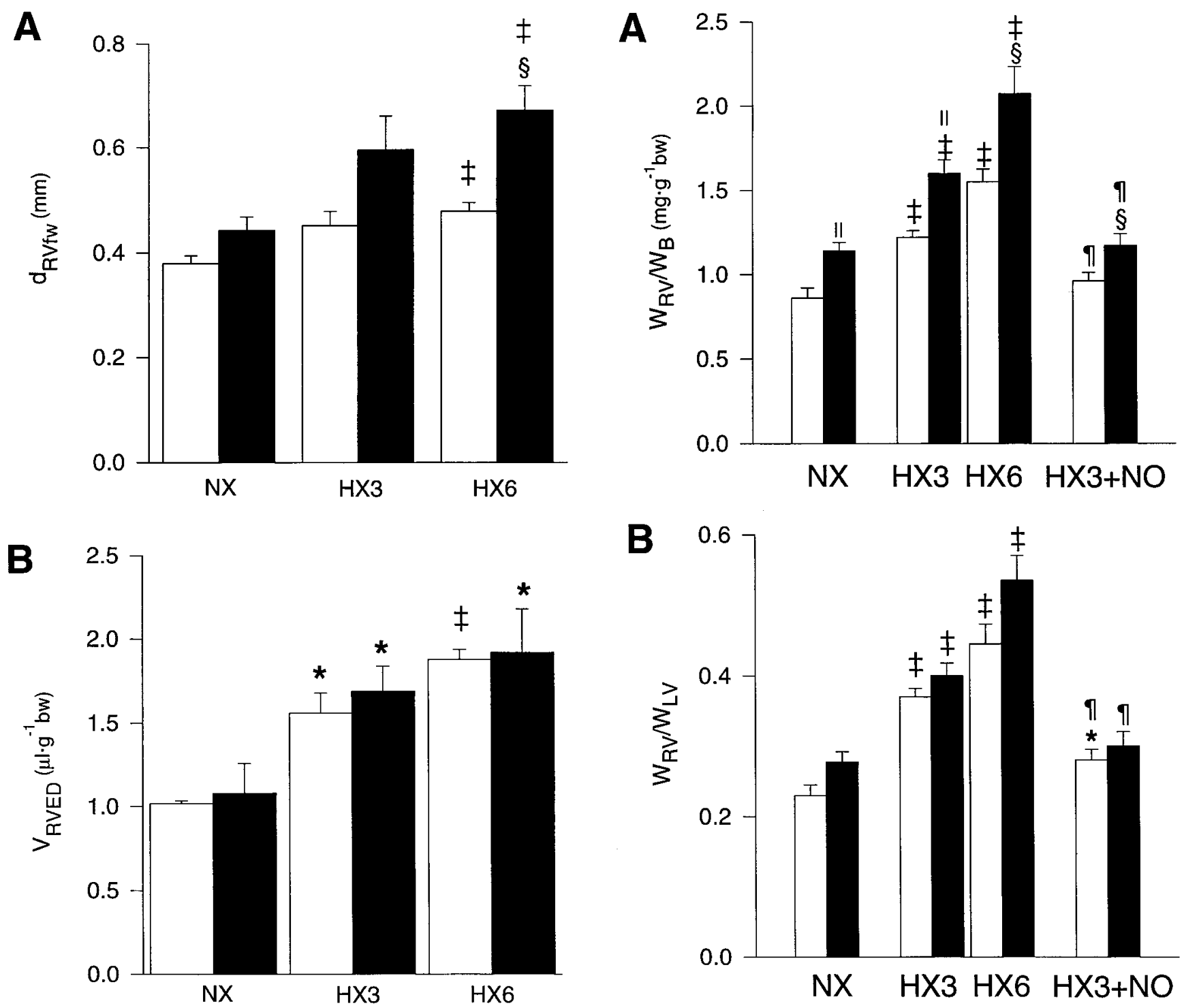

Figure 5. RV free wall thickness $\left(d_{R V f w}, A\right)$ and right-ventricular enddiastolic volume $\left(V_{R V E D}, B\right)$ of SV129 wild-type mice (open bars) and NOS3-deficient mice (solid bars) as determined by transeophageal echocardiography, under normoxic conditions $(N X)$ and after $3 \mathrm{wk}$ $(H X 3)$ and $6 \mathrm{wk}(H X 6)$ of breathing at $\mathrm{FiO}_{2} 0.11$. Note that there was a greater increase in $\mathrm{RV}$ free wall thickness in NOS3-deficient mice than in wild-type mice $(A)$. In both wild-type and NOS3-deficient mice, RV dilation occurred $(B) .{ }^{*} P<0.05,{ }^{\ddagger} P<0.01$ value differs significantly from value of corresponding normoxic group. ${ }^{\S} P<0.05$ value differs significantly from value of wild-type mice in the same exposure group. Data are $\overline{\mathrm{x}} \pm \mathrm{SE}$ of four to six independent experiments per group.

obtained in C57 Black/6 wild-type mice under normoxic conditions $(n=10)$ and after breathing for 3 wk at $\mathrm{FiO}_{2} 0.11(n=9)$ did not differ from the corresponding values in normoxic SV129 wild-type mice and in SV129 wild-type mice that breathed at $\mathrm{FiO}_{2} 0.11$ for $3 \mathrm{wk}$ (data not shown).

Hematocrit. The hematocrit (Hct), sampled from the arterial line immediately after its insertion and before any volume administration, was $51 \pm 3 \%$ in SV129 wild-type mice and

Figure 6. Ratio of RV weight to body weight $\left(W_{R V} / W_{B}, A\right)$ and Fulton's ratio $\left(W_{R V} / W_{L V}, B\right)$ in SV129 wild-type mice (open bars) and NOS3-deficient mice (solid bars) under normoxic conditions $(N X)$, after 3 wk of breathing at $\mathrm{FiO}_{2} 0.11(H X 3)$, after 3 wk of breathing at $\mathrm{FiO}_{2} 0.11$ with $20 \mathrm{ppm} \mathrm{NO}$ added $(H X 3+N O)$, and after 6 wk of breathing at $\mathrm{FiO}_{2} 0.11$ (HX6). Note that RV hypertrophy caused by chronic hypoxia was enhanced by NOS3-deficiency $(A$ and $B)$. Also note that the changes in RV weight as induced by $3 \mathrm{wk}$ of hypoxia were prevented by simultaneous NO inhalation $(H X 3+\mathrm{NO}) . * P<$ $0.05,{ }^{\ddagger} P<0.001$ value differs significantly from value of corresponding normoxic group. ${ }^{\S} P<0.05,{ }^{\|} P<0.001$ value differs significantly from value of wild-type mice in the same exposure group. ${ }^{\mathbb{T}} P<0.001$ value significantly differs from value of corresponding HX3 group. Data are $\overline{\mathrm{x}} \pm \mathrm{SE}$ of independent experiments: NOS3 $+/+\mathrm{NX}(n=21)$, NOS3-/- NX $(n=17), \mathrm{NOS} 3+/+\mathrm{HX} 3(n=38), \mathrm{NOS} 3-/-\mathrm{HX} 3$ $(n=41), \mathrm{NOS} 3+/+\mathrm{HX} 6(n=5), \mathrm{NOS} 3-/-\mathrm{HX} 6(n=5)$, $\mathrm{NOS} 3+/+\mathrm{HX}+\mathrm{NO}(n=17), \mathrm{NOS} 3-/-\mathrm{HX}+\mathrm{NO}(n=20)$.

$49 \pm 3 \%$ in NOS3-deficient mice under normoxic conditions $(P=\mathrm{NS})$. After breathing at $\mathrm{FiO}_{2} 0.11$ for 3 wk, the Hct was increased in both SV129 wild-type mice $(P<0.01)$ and NOS3deficient mice $(P<0.001$, Fig. $7 A)$. The Hct in NOS3-defi- 

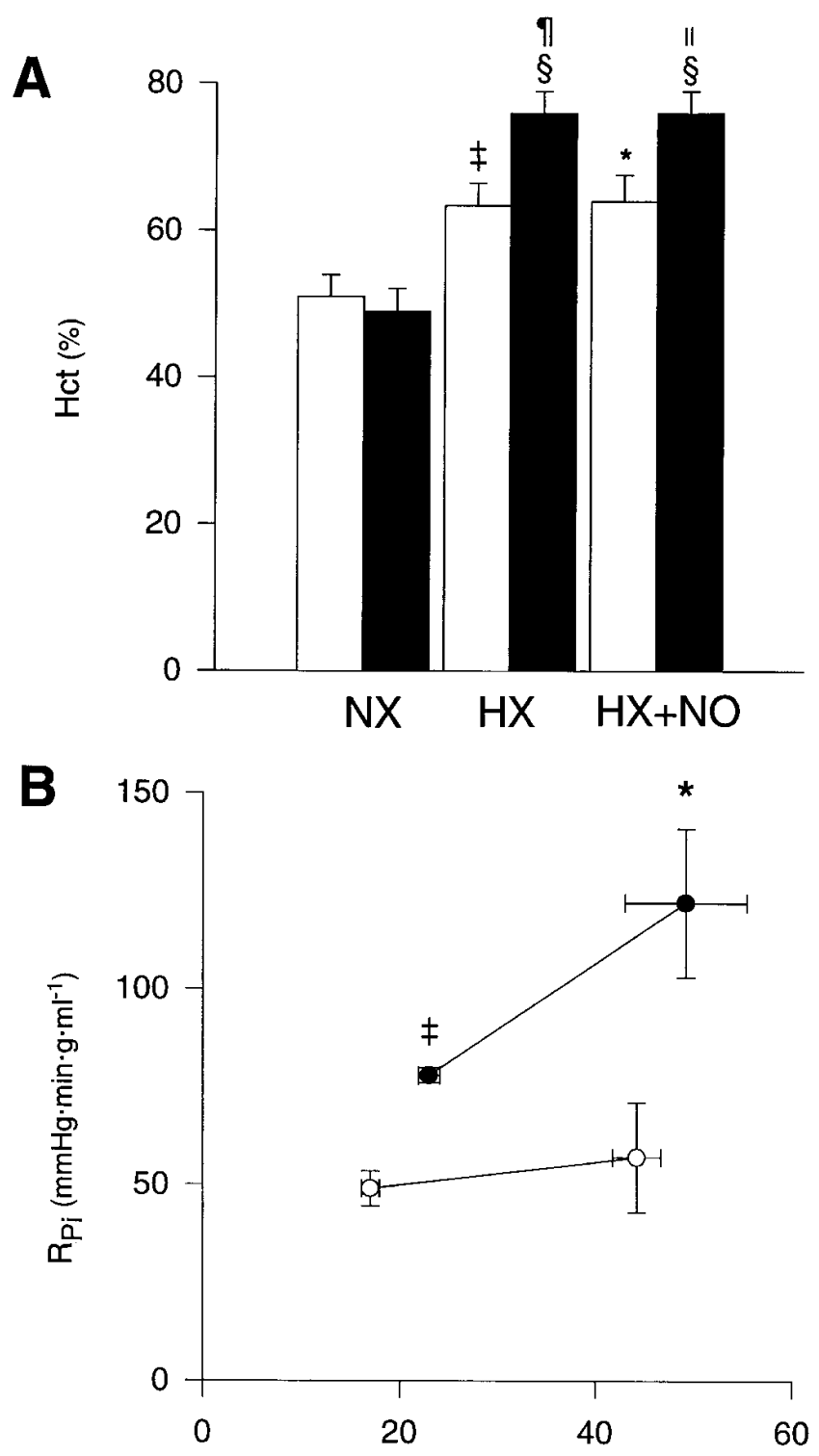

Hct $(\%)$

Figure 7. (A) Hematocrit (Hct) in wild-type mice (open bars) and NOS3-deficient mice (solid bars) under normoxic conditions $(N X)$, after 3 wk of breathing at $\mathrm{FiO}_{2} 0.11(H X)$ and after 3 wk of breathing at $\mathrm{FiO}_{2} 0.11$ with $20 \mathrm{ppm} \mathrm{NO}$ added $(H X+N O)$. Blood for Hct determination was obtained immediately after insertion of the arterial line. The Hct was significantly greater in chronically hypoxic NOS3deficient mice, independent of simultaneous NO inhalation. $* P<$ $0.05,{ }^{\ddagger} P<0.01,{ }^{\S} P<0.001$ value differs significantly from value of corresponding normoxic group. $\| P<0.01,{ }^{\mathbb{T}} P<0.001$ value differs significantly from value of wild-type mice in the same exposure group. Data are $\overline{\mathrm{x}} \pm \mathrm{SE}$ of independent experiments: NOS3 $+/+\mathrm{NX}$ $(n=9), \mathrm{NOS} 3-1-, \mathrm{NX}(n=11), \mathrm{NOS} 3+1+\mathrm{HX}(n=17), \mathrm{NOS} 3-1-$ $\mathrm{HX}(n=17), \mathrm{NOS} 3+1+\mathrm{HX}+\mathrm{NO}(n=13), \mathrm{NOS} 3-1-\mathrm{HX}+\mathrm{NO}$ $(n=14)$. (B) Effects of hemodilution with $5 \%$ bovine albumin on incremental total pulmonary vascular resistance $\left(R_{P I}\right)$ at thoracotomy in four wild-type mice (open symbols) and four NOS3-deficient mice (solid symbols) that breathed for 3 wk at $\mathrm{FiO}_{2} 0.11$. Note that $\mathrm{R}_{\mathrm{PI}}$ in NOS3-deficient mice was significantly greater than in wild-type mice both before $\left({ }^{*} P<0.05\right)$ and after hemodilution $\left({ }^{\ddagger} P<0.001\right)$. cient mice was greater than the Hct in SV129 wild-type mice (76 \pm 3 vs $63 \pm 3 \%, P<0.001$ ). The Hct measured in C57 Black $/ 6$ wild-type mice that breathed for 3 wk at $\mathrm{FiO}_{2} 0.11(59 \pm 2 \%$, $n=6)$ did not differ from that of SV129 wild-type mice that breathed for $3 \mathrm{wk}$ at $\mathrm{FiO}_{2} 0.11(n=17, P=\mathrm{NS}$, Fig. $7 A)$. In both SV129 wild-type mice and NOS3-deficient mice that breathed for 3 wk at $\mathrm{FiO}_{2} 0.11$ with 20 ppm NO added, the Hct did not differ from that induced by breathing at $\mathrm{FiO}_{2} 0.11$ for 3 wk alone (Fig. $7 A$ ).

To assess the contribution of the elevated Hct to the incremental pulmonary vascular resistance $\left(\mathrm{R}_{\mathrm{PI}}\right)$ of chronically hypoxic mice, we conducted hemodilution experiments after thoracotomy in SV129 wild-type mice and NOS3-deficient mice that had breathed at $\mathrm{FiO}_{2} 0.11$ for 3 wk. Blood $(1 \mathrm{ml})$ was withdrawn from the arterial line and simultaneously replaced with $5 \%$ bovine albumin via the venous catheter, maintaining the $\mathrm{Q}_{\mathrm{LTA}}$ at a stable value. In SV129 wild-type mice, hemodilution did not alter the $\mathrm{R}_{\mathrm{PI}}$. In contrast, as shown in Fig. $7 \mathrm{~B}$, the $\mathrm{R}_{\mathrm{PI}}$ decreased after hemodilution in NOS3-deficient mice, but remained higher than that of SV129 wild-type mice both before $(P<0.05)$ and after $(P<0.001)$ hemodilution.

\section{Discussion}

The major finding of this study is that a congenital deficiency of NOS3 in mice markedly augmented pulmonary vasoconstriction, and thus the pulmonary and RV systolic hypertension, which was induced by 3 wk of hypoxic stress (Fig. 1 and Table I). Moreover, pulmonary vascular remodeling after $3 \mathrm{wk}$ of hypoxia was enhanced by congenital NOS3 deficiency (Fig. 3).

Congenital absence of NOS3 amplified the degree of RV hypertrophy induced by 3 and 6 wk of hypoxia, as determined by both in vivo transesophageal echocardiographic RV wall thickness measurements (Fig. 4 and Fig. 5 A) and in vitro RV weight measurements (Fig. 6). RV dilatation induced by breathing at $\mathrm{FiO}_{2} 0.11$ for 3 and 6 wk and measured by TEE as $\mathrm{V}_{\mathrm{RVED}}$, however, was not enhanced by congenital NOS3 deficiency (Fig. 5 B).

In mice with and without congenital NOS3 deficiency, inhalation of 20 ppm NO during the 3 wk of hypoxia did not prevent pulmonary hypertension (Table I) but completely prevented RV hypertrophy (Fig. 6). The polycythemia induced by 3 wk of hypoxia was substantially enhanced by congenital NOS3 deficiency (Fig. $7 A$ ). Polycythemia was not primarily responsible for RV hypertrophy, since RV hypertrophy, but not polycythemia, was completely prevented by chronic NO inhalation (Figs. 6 and 7).

Because the two parental strains of NOS3-deficient mice, SV129 and C57 Black/6 wild-type mice, did not hemodynamically differ at baseline and had similar responses to hypoxia in all of the measured parameters, it is likely that the differences we observed are due to NOS3 deficiency and not due to differences in strains.

Chronic hypoxic pulmonary hypertension and NOS3. Several studies have reported that endothelial NO formation is impaired in the pulmonary arteries of patients with chronic hypoxic lung disease (17) and in the isolated pulmonary arteries and the isolated-perfused lungs of animals that have developed chronic hypoxic pulmonary hypertension $(7,8,18)$. The loss of endothelial NO release has been attributed to decreased pulmonary vascular NOS3 expression in patients with chronic pulmonary hypertension (1), although this is disputed 
(4). More recent studies have suggested that increased vascular NOS3 expression in experimental chronic hypoxic pulmonary hypertension may actually contribute to the etiology of pulmonary hypertension and vascular remodeling $(10,19)$, since NO can stimulate the proliferation of smooth muscle cells (20). Our data clearly demonstrate that in mutant mice the deficiency of NOS3 aggravates pulmonary hypertension, pulmonary vascular remodeling, and RV hypertrophy in response to chronic hypoxic exposure. A major proliferative and prohypertensive role of NOS 3 in the pulmonary circulation as suggested by Xue et al. (10) seems unlikely. Rather, NO production by NOS3 in mice appears to reduce hypoxic pulmonary hypertension and pulmonary vascular remodeling as well as RV hypertrophy.

Effects of chronic NO inhalation on pulmonary hypertension and $R V$ hypertrophy. It is well established that the inhalation of NO reverses acute hypoxic pulmonary vasoconstriction $(21,22)$ and prevents chronic hypoxic remodeling of the pulmonary vasculature and right ventricle. Inhalation of $20 \mathrm{ppm}$ NO during hypoxia prevents RV hypertrophy and pulmonary vascular remodeling in both newborn (13) and adult rats $(14,23)$.

We hypothesized that the pulmonary vascular consequences of chronic hypoxia in NOS3-deficient mice would be prevented by simultaneous NO replacement. Both wild-type and NOS3-deficient mice were exposed to low oxygen tensions with 20 ppm NO added for $3 \mathrm{wk}$. After removal from the exposure chambers, pulmonary vasoconstriction, pulmonary and RV systolic hypertension were present in both NOS3-deficient and wild-type mice. However, hypoxic RV hypertrophy was completely prevented by chronic 20 ppm NO inhalation in both genotypes. Although we did not study vascular morphometry after NO inhalation, results of previous studies suggest that NO inhalation prevented hypoxia-induced neomuscularization $(13,14)$.

Because NO inhalation prevented RV hypertrophy in mice breathing at $\mathrm{FiO}_{2} 0.11$, it is likely that the pulmonary vascular resistance and artery pressure were considerably lower while the mice were in the chamber. After removal from the chamber, pulmonary vasoconstriction occurred. Rebound pulmonary vasoconstriction has been previously reported after discontinuation of NO inhalation in both clinical and experimental studies $(23,24)$. To test whether this rebound pulmonary vasoconstriction is reversible by NO, we added $20 \mathrm{ppm}$ to the inspired gas mixture during the hemodynamic measurements. Acute NO inhalation caused sustained pulmonary vasodilation in mice which had chronically inhaled NO suggesting that pulmonary vasoconstriction and hypertension were caused by NO withdrawal.

In contrast, mice that chronically breathed at low oxygen tensions without NO had an impaired pulmonary vasoreactivity in response to acute NO inhalation. Vascular remodeling and neomuscularization after chronic hypoxia might have resulted in irreversible restriction of the vascular bed, and thus, nonresponsiveness to inhaled NO. This might be in part due to reduced activity of soluble guanylate cyclase, an NO receptor which has been reported to be decreased in isolated pulmonary artery segments obtained from rats that breathed at low oxygen tensions for $7 \mathrm{~d}(25)$.

$R V$ function during chronic hypoxia. A unique aspect of this study is that murine RV volumes and function were assessed noninvasively by transesophageal echocardiography allowing accurate visualization of the right ventricle and estima- tion of its function in vivo. After breathing at low oxygen tensions for 3 and $6 \mathrm{wk}$, several alterations of RV structure and function were noted. The right ventricle became hypertrophied, as measured by echocardiographic wall thickness measurements. This correlated with RV weight measurements in vitro. The degree of RV hypertrophy after hypoxia was increased by congenital NOS3 deficiency. However, the right ventricle appeared dilated at end-diastole and end-systole in both chronically hypoxic mice genotypes to a similar degree (Fig. 5). Although the RV ejection fraction was slightly decreased (from $\sim 52 \%$ to $\sim 45 \%$ ), the stroke volume and cardiac output were preserved. This pattern has been observed in chronic lung disease with hypoxemia and RV pressure overload (26). Since the RV ejection fraction is very dependent on ventricular loading conditions (27), the small decrease might be due to an increased pulmonary artery pressure without evidence of decreased RV contractility.

Contribution of polycythemia to chronic hypoxic pulmonary hypertension in NOS3-deficiency. One important component of the pulmonary hypertension associated with chronic hypoxia is the polycythemia (28). Since the initial hematocrit was higher in NOS3-deficient mice than in wild-type mice after $3 \mathrm{wk}$ of hypoxia we examined the contribution of hematocrit to pulmonary vascular resistance in hemodilution experiments.

It was technically not possible to measure pulmonary vascular resistance at closed chest at the initial hematocrit (65$75 \%$, Fig. $7 A$ ). Thoracotomy was necessary to place a pulmonary artery catheter and flow probe, and the associated blood loss and replacement produced hemodilution $\sim 25 \%$ (see Fig. 7, $A$ and $B$ ). In chronically hypoxic wild-type mice, the pulmonary vascular resistance was not further decreased by hemodilution from 50 to $20 \%$ hematocrit (Fig. 7 B). However, due to a critical increase of blood viscosity between 40 and $60 \%$ hematocrit as shown in rats after prolonged hypoxia (28), the pulmonary vascular resistance was likely to be greatest at the initial high hematocrit $(\sim 65 \%)$.

In contrast, hemodilution from 50 to $20 \%$ hematocrit in chronically hypoxic NOS3-deficient mice substanially decreased the pulmonary vascular resistance. This effect appeared unrelated to blood viscosity, since hematocrit was similar to that in chronic hypoxic wild-type mice. This confirms prior results obtained in isolated rat and rabbit lungs $(29,30)$ : NOS inhibition caused a hematocrit-dependent, leukocyte- and platelet-independent increase of pulmonary vascular resistance. In these reports pulmonary vascular resistance was not affected by NOS inhibitors when lungs were perfused with plasma, buffer, or oxyhemoglobin at the same viscosity as blood $(29,30)$.

The precise mechanism by which erythrocytes and NOS interact to modulate the pulmonary vascular resistance are not known. It is possible that increased concentrations of erythrocytes may cause turbulent flow, increasing shear stress at the vascular endothelium and promote endothelial NO synthesis and release (31).

Our results, however, do not support the assumption that the larger initial hematocrit of NOS3-deficient mice accounted for their greater degree of RV hypertrophy during hypoxia. Chronic NO inhalation completely prevented RV hypertrophy, but not polycythemia, suggesting that, if enough NO is present to oppose hypoxic pulmonary hypertension and vasoconstriction, even a very high hematocrit ( 65-75\%) does not impose sufficient additional work load upon the right ventricle to cause hypertrophy. 
The mechanism resulting in a greater level of polycythemia in NOS3-deficient mice is also not yet understood. Possible pathways may include reduced renal blood flow caused by increased renin plasma concentrations in NOS3-deficient mice (32), which may enhance renal erythropoietin production during chronic hypoxic stress. However, enhanced erythropoietin production, induced by hypoxia in isolated perfused rat kidneys, is blocked by the administration of the NOS inhibitor L-NAME (33), suggesting that NOS (and not the absence or inhibition of NOS) activates erythropoiesis.

Summary and conclusion. Targeted disruption of the NOS3 gene in mice, causes mild pulmonary and RV hypertension under normoxic conditions, but substantially augments the degree of pulmonary vascular remodeling, pulmonary and RV hypertension, and RV hypertrophy during chronic hypoxic exposure, suggesting that NOS3 plays an important role in modulating the pulmonary vasoconstriction, hypertension, and remodeling produced by exposure to chronic hypoxia. Our findings suggest that genetic deficiencies of the production of a vasodilator substance may only become clearly apparent when an environmental stress (such as hypoxia) requires the vasodilator to counterbalance vasoconstrictor tone.

\section{Acknowledgments}

The authors would like to thank Maria del Mar Aris, Jonathan Hromi, and Margaretha Jacobson for technical help and Dr. YuChiao Chang for statistical advice. We are also grateful to Dr. Patrick R. Hunziker for his assistance with the echocardiographic image analysis.

This study was supported by United States Public Health Service grant HL-42397 (Drs. Zapol and Bloch). Dr. Steudel and Dr. Weimann are Research Fellows supported by the Deutsche Forschungsgemeinschaft (German Research Association, STE 835/1-2 and WE2114/1-1). Dr. Scherrer-Crosbie is a Research Fellow supported by the Harold M. English Fellowship (Harvard Medical School). Drs. Bloch and Huang are Established Investigators of the American Heart Association.

\section{References}

1. Giaid, A., and D. Saleh. 1995. Reduced expression of endothelial nitric oxide synthase in the lungs of patients with pulmonary hypertension. N. Engl. J. Med. 333:214-221.

2. Steudel, W., F. Ichinose, P.L. Huang, W.E. Hurford, R.C. Jones, J.A. Bevan, M.C. Fishman, and W.M. Zapol. 1997. Pulmonary vasoconstriction and hypertension in mice with targeted disruption of the endothelial nitric oxide synthase (NOS 3) gene. Circ. Res. 81:34-41.

3. Gruetter, C.A., D.Y. Gruetter, J.E. Lyon, P.J. Kadowitz, and L.J. Ignarro. 1981. Relationship between cyclic guanosine $3^{\prime}: 5^{\prime}$-monophosphate formation and relaxation of coronary arterial smooth muscle by glyceryl trinitrate, nitroprusside, nitrite and nitric oxide: effects of methylene blue and methemoglobin. J. Pharmacol. Exp. Ther. 219:181-186.

4. Xue, C., and R.A. Johns. 1995. Endothelial nitric oxide synthase in the lungs of patients with pulmonary hypertension. N. Engl. J. Med. 333:1642-1644.

5. Zapol, W.M., and R. Jones. 1987. Vascular components of ARDS. Clinical pulmonary hemodynamics and morphology. Am. Rev. Respir. Dis. 136:471-474.

6. Zapol, W.M., K. Kobayashi, M.T. Snider, R. Greene, and M.B. Laver. 1977. Vascular obstruction causes pulmonary hypertension in severe acute respiratory failure. Chest. 71:306-307.

7. Shaul, P.W., L.B. Wells, and K.M. Horning. 1993. Acute and prolonged hypoxia attenuate endothelial nitric oxide production in rat pulmonary arteries by different mechanisms. J. Cardiovasc. Pharmacol. 22:819-827.

8. Adnot, S., B. Raffestin, S. Eddahibi, P. Braquet, and P.E. Chabrier. 1991. Loss of endothelium-dependent relaxant activity in the pulmonary circulation of rats exposed to chronic hypoxia. J. Clin. Invest. 87:155-162.

9. Shaul, P.W., A.J. North, T.S. Brannon, K. Ujiie, L.B. Wells, P.A. Nisen, C.J. Lowenstein, S.H. Snyder, and R.A. Star. 1995. Prolonged in vivo hypoxia enhances nitric oxide synthase type I and type III gene expression in adult rat lung. Am. J. Respir. Cell Mol. Biol. 13:167-174.

10. Xue, C., and R.A. Johns. 1996. Upregulation of nitric oxide synthase correlates temporally with onset of pulmonary vascular remodeling in the hypoxic rat. Hypertension (Dallas). 28:743-753.

11. Hampl, V., S.L. Archer, D.P. Nelson, and E.K. Weir. 1993. Chronic EDRF inhibition and hypoxia: effects on pulmonary circulation and systemic blood pressure. J. Appl. Physiol. 75:1748-1757.

12. Huang, P.L., Z. Huang, H. Mashimo, K.D. Bloch, M.A. Moskowitz, J.A Bevan, and M.C. Fishman. 1995. Hypertension in mice lacking the gene for endothelial nitric oxide synthase. Nature. 377:239-242.

13. Roberts, J.D., Jr., C.T. Roberts, R.C. Jones, W.M. Zapol, and K.D. Bloch. 1995. Continuous nitric oxide inhalation reduces pulmonary arterial structural changes, right ventricular hypertrophy, and growth retardation in the hypoxic newborn rat. Circ. Res. 76:215-222.

14. Roos, C.M., D.U. Frank, C. Xue, R.A. Johns, and G.F. Rich. 1996. Chronic inhaled nitric oxide: effects on pulmonary vascular endothelial function and pathology in rats. J. Appl. Physiol. 80:252-260.

15. Scherrer-Crosbie, M., W. Steudel, G. Foster, W.M. Zapol, and M.H. Picard. 1997. Validation of three-dimensional transesophageal echocardiography for right ventricular volumes and function in mice. Circulation. 96:I698a. (Abstr.)

16. Scherrer-Crosbie, M., W. Steudel, G. Foster, W.M. Zapol, and M.H. Picard. 1997. Validation of transesophageal echocardiography for the assessment of right ventricular hypertrophy in the mouse. Circulation. 96:I699a. (Abstr.)

17. Dinh-Xuan, A.T., T.W. Higenbottam, C.A. Clelland, J. Pepke-Zaba, G. Cremona, A.Y. Butt, S.R. Large, F.C. Wells, and J. Wallwork. 1991. Impairment of endothelium-dependent pulmonary-artery relaxation in chronic obstructive lung disease. N. Engl. J. Med. 324:1539-1547.

18. Carville, C., B. Raffestin, S. Eddahibi, Y. Blouquit, and S. Adnot. 1993. Loss of endothelium-dependent relaxation in proximal pulmonary arteries from rats exposed to chronic hypoxia: effects of in vivo and in vitro supplementation with L-arginine. J. Cardiovasc. Pharmacol. 22:889-896.

19. Xue, C., A. Rengasamy, T.D. Le Cras, P.A. Koberna, G.C. Dailey, and R.A. Johns. 1994. Distribution of NOS in normoxic vs. hypoxic rat lung: upregulation of NOS by chronic hypoxia. Am. J. Physiol. 267:L667-L678.

20. Hassid, A., H. Arabshahi, T. Bourcier, G.S. Dhaunsi, and C. Matthews. 1994. Nitric oxide selectively amplifies FGF-2-induced mitogenesis in primary rat aortic smooth muscle cells. Am. J. Physiol. 267:H1040-H1048.

21. Frostell, C.G., H. Blomqvist, G. Hedenstierna, J. Lundberg, and W.M Zapol. 1993. Inhaled nitric oxide selectively reverses human hypoxic pulmonary vasoconstriction without causing systemic vasodilation. Anesthesiology. 78:427-435.

22. Frostell, C., M.D. Fratacci, J.C. Wain, R. Jones, and W.M. Zapol. 1991. Inhaled nitric oxide. A selective pulmonary vasodilator reversing hypoxic pulmonary vasoconstriction. Circulation. 83:2038-2047.

23. Kouyoumdjian, C., S. Adnot, M. Levame, S. Eddahibi, H. Bousbaa, and B. Raffestin. 1994. Continuous inhalation of nitric oxide protects against development of pulmonary hypertension in chronically hypoxic rats. J. Clin. Invest. 94:578-584.

24. Rossaint, R., K.J. Falke, F. Lopez, K. Slama, U. Pison, and W.M. Zapol. 1993. Inhaled nitric oxide for the adult respiratory distress syndrome. N. Engl. J. Med. 328:399-405.

25. Crawley, D.E., L. Zhao, M.A. Giembycz, S. Liu, P.J. Barnes, R.J. Winter, and T.W. Evans. 1992. Chronic hypoxia impairs soluble guanylyl cyclasemediated pulmonary arterial relaxation in the rat. Am. J. Physiol. 263:L325L332.

26. Biernacki, W., D.C. Flenley, A.L. Muir, and W. MacNee. 1988. Pulmonary hypertension and right ventricular function in patients with COPD. Chest. 94:1169-1175.

27. Brent, B.N., H.J. Berger, R.A. Matthay, D. Mahler, L. Pytlik, and B.L. Zaret. 1982. Physiologic correlates of right ventricular ejection fraction in chronic obstructive pulmonary disease: a combined radionuclide and hemodynamic study. Am. J. Cardiol. 50:255-262.

28. Barer, G.R., D. Bee, and R.A. Wach. 1983. Contribution of polycythaemia to pulmonary hypertension in simulated high altitude in rats. J. Physiol. (Lond). 336:27-38.

29. Uncles, D.R., M.O. Daugherty, D.U. Frank, C.M. Roos, and G.F. Rich. 1996. Nitric oxide modulation of pulmonary vascular resistance is red blood cell dependent in isolated rat lungs. Anesth. Analg. 83:1212-1217.

30. Sprague, R.S., M.L. Ellsworth, A.H. Stephenson, and A.J. Lonigro. 1996. ATP: the red blood cell link to NO and local control of the pulmonary circulation. Am. J. Physiol. 271:H2717-H2722.

31. Takahashi, M., T. Ishida, O. Traub, M.A. Carson, and B.C. Berk. 1997. Mechanotransduction in endothelial cells: temporal signaling events in response to shear stress. J. Vasc. Res. 34:212-219.

32. Shesely, E.G., N. Maeda, H.S. Kim, K.M. Desai, J.H. Krege, V.E. Laubach, P.A. Sherman, W.C. Sessa, and O. Smithies. 1996. Elevated blood pressures in mice lacking endothelial nitric oxide synthase. Proc. Natl. Acad. Sci. USA. 93:13176-13181.

33. Yoshioka, K., and J.W. Fisher. 1995. Nitric oxide enhancement of erythropoietin production in the isolated perfused rat kidney. Am. J. Physiol. 269: C917-C922. 